\title{
THE ROLE OF SCHOOL ADMINISTRATIVE SUPPORT AND PRIMARY SCHOOL TEACHERS' ICT LITERACY TO INTEGRATE ICT INTO THE CLASSROOMS IN PAHANG, MALAYSIA
}

\author{
Zuraidah Binti Baharuldin ${ }^{a *}$, Shahrir Bin Jamaluddin ${ }^{a}$, Mohd Shahril Nizam Bin \\ Shaharom ${ }^{\mathrm{a}}$
}

${ }^{\mathrm{a}}$ Faculty of Education, University of Malaya, Malaysia

*Corresponding Author's Email: zuraidahbaharuldin@siswa.um.edu.my

\begin{abstract}
This study aimed to look at the role of information and communications technology (ICT) literacy of teachers as a mediator between the school administrative support and ICT competence of primary school teachers in Pahang. The researchers developed a mediation model based on relevant literature reviews and subsequently tested the model. This study used a total survey design. The researchers employed stratified cluster sampling to select the pilot study and the actual study samples randomly. A total of 514 teachers were involved in the pilot study and 530 teachers were involved in the actual study. The Cronbach's alpha for instrument was .954 while the validity of the instrument used was determined using the SEM-AMOS method. The results based on the pilot data indicated a good model fit with chisquare $=212.406, d f=111, p<.001, \mathrm{CMIN} / d f=3.662, \mathrm{GFI}=.938, \mathrm{CFI}=.941$, and RMSEA $=.072$, whereas results based on the actual study also indicated a good model fit with chi-square $=204.839, d f=58, p<.001, \mathrm{CMIN} / d f=3.532, \mathrm{GFI}=.942$, $\mathrm{CFI}=.950$, and RMSEA $=.069$. The findings showed that there were direct and indirect effects of school administrative support and teachers' ICT literacy on teachers' ICT competences. There was a statistically significant relationship $(p<.05)$ between school administrative support and teachers' ICT competence and an indirect effect through teachers' ICT literacy as a mediator. Hence, teachers' ICT literacy acts a partial mediator in the model. This study shows that school administrative support and teachers' ICT literacy play an important role in shaping teachers' ICT competence. Furthermore, the study provides further evidence that school principals through teachers' ICT literacy play an important role in integrating ICT into the classroom. School administrators should equip themselves with formal training in technological leadership so that they can better contribute to aiding school teachers to better integrate ICT into their teaching and learning.
\end{abstract}

Keywords: school administrative support, ICT literacy, ICT competence, mediation analysis, ICT integration in education

\section{INTRODUCTION}

\section{Background of Research}

The need for ICT integration in education and the emphasis on teacher competence in ICT is highlighted in the National Education Policy 2012 (Ministry of Education Malaysia, 2012). The efforts of the Ministry of Education (MOE) to enhance teachers' ICT competences in the teaching and learning has also been highlighted in the Interim Strategic Plan 2011-2020 (Wei, Piaw, Kannan, \& Moulod, 2016). This has been supported by the Malaysian Education Development Plan Report 2013-2025 (MOE, 2013), which states that teachers are important agents who are responsible 
for making ICT literacy a success in the field of education. The integration of ICT in education in Malaysia involves three stages: 1) First wave (2013-2015) is to introduce ICT policies, 2) Second wave (2016-2020) is to introduce innovation in ICT, and 3) Third wave (2021-2025) entails innovation in the whole system.

In view of this, school administrative support in the form of transformational leadership can be a key driving force for teachers to achieve the outlined benchmarks so that they are competent enough to manage and implement ICT in education (Veeriah, Chua, \& Siaw, 2017). Additionally, teachers must facilitate and inspire student learning and creativity, design and develop digital learning and assessment experiences, demonstrate how to work and learn in the digital age, promote and model responsible digital communities as well as engage in professional development and teacher leadership (Adams, A. Samat, \& Abu Samah, 2018; Mohamed, Abdul Razak, \& Zuraidah, 2018).

School administrative support serves as a supporting agent for ICT integration in schools. In this study, school administrative support is adapted and measured from an instrument developed by Simin and Mohammed Sani (2015). Five items measured primary and secondary school teachers' perceptions of school administrative support in integrating ICT into teaching and learning. The items are support from school administrators, teaching allocation, mastery of ICT use, instructional design of teaching with the aid of ICT, and teachers' professional development. As advocates of ICT integration, school administrators face challenges such as the development of ICT infrastructure in schools, provision of high-speed internet access, updating and managing ICT assets, provision of interactive teaching and learning sessions, teachers' mastery of the use of ICT in teaching and learning, providing teachers with ICT skills training to enhance the ICT competence and ICT community culture amongst students and school staff (Abdullah, Khalid, \& Mohd Hamzah, 2015). Salehudin (2016) noted that factors influencing the support of school administrators to integrate ICT include developing ICT competence, providing training for teachers, providing a complete infrastructure to promote computer literacy, and developing effective school evaluation planning.

Teachers' ICT literacy is measured by an instrument developed and validated by Lau and Yuen (2014). ICT literacy (17 items) consists of information literacy (seven items), internet literacy (five items), and computer literacy (five items). Information literacy involves teachers' ability to extract information from the internet and disseminate the information to the students. Internet literacy includes teachers' ability to browse the internet in an effort to access learning materials and computer literacy involves teachers' ability to use computer software for the purpose of teaching and learning.

Teachers' ICT competence was developed by Koh, Chai, and Tsais (2012). The instrument consists of 29 items that were developed based on the technological pedagogical content knowledge (TPACK) model (Koehler \& Mishra, 2006). According to the TPACK model, teachers' ICT competence is based on three main components, namely technological knowledge, pedagogical knowledge, and content knowledge. These three components explain teachers' ability to integrate ICT into schools. Seven subdomains were identified: i) content knowledge, ii) pedagogical knowledge, iii) pedagogical content knowledge, iv) technological knowledge, v) technological pedagogical knowledge, vi) technological content knowledge, and vii) technological pedagogical content knowledge. 
At the same time, the MOE focuses on ICT literacy based on the Malaysian Education Development Plan Report 2013-2025 (MOE, 2013). Formal ICT training and teachers' experience in using ICT have been found to influence and contribute to teachers' ICT literacy (Rosnaini \& Mohd Arif, 2010). According to Ammah (2017), a teacher should possess ICT literacy as it enhances personal professionalism and influences the level of teachers' ICT competence.

\section{Problem Statement}

School administrative support and ICT literacy play important roles in the development of ICT competences among primary school teachers. Recent studies (Abdullah et al., 2015; Blau \& Shamir-Inbal, 2016; Salehudin, 2016) propose that administrative school support plays a role in enhancing ICT integration in schools. However, Simin and Mohammed Sani (2015) observed that a lack of support from higher management prevent teachers from using ICT. In addition, school administrators are said to not provide adequate training and professional development for teachers to utilise ICT in the classroom. In fact, Vella, Burmeister, Ceric, and Barnden (2017) suggested that the role of school administrators should be refined to enable ICT integration in schools.

School administrators as technology leaders are responsible for the development of computer literacy amongst teachers (Salehudin, 2016). Therefore, school administrative support plays an important role in developing teacher ICT literacy, information literacy, internet literacy, and computer literacy so that teachers' ICT competence can be further enhanced. This is supported by a study conducted by Mahmud and Ismail (2010) which stated that ICT literacy, ICT knowledge, and teachers' ICT skills are still at a moderate level. Ammah (2017) put forward that every teacher should have information literacy, media literacy, and ICT literacy to develop their ICT competence potential.

The ICT usage in schools is still unable to meet the quantity and quality of teachers, and pupils and teachers' ICT competence is still at a low level (Fong, Ch'ng, \& Por, 2013). On the other hand, a study by Vitanova, Atanasova-Pachemska, lliev, and Pachemska (2015) found that the level of teachers' ICT competence is high. However, studies on teacher competence such as Mohd Sani (2016) also revealed that teachers' ICT competence is still low. As such, Vanderlinde, Aesaert, and Van Braak (2014) and Baturay, Gokcearslan, and Ke (2017) proposed teachers' ICT competence level to be studied.

In conclusion, based on the research problem above, the researchers developed and subsequently tested a model to obtain the latest explanation of the role of school administrative support, ICT literacy, and teachers' ICT competence in primary schools. This model looks specifically at the role of teachers' ICT literacy as it mediates the relationship between school administrative support and teachers' ICT competence among primary school teachers in Pahang.

\section{Purpose of Study}

This study aimed to explain the role of ICT literacy as a mediator in the model by examining the direct and indirect effects of school administrative support on ICT competence of primary school teachers. Based on the purpose of the study, the researchers developed the following hypotheses: 
Null hypothesis (Ho): Teachers' ICT literacy does not significantly mediate the relationship between school administrative support and teachers' ICT competence. Alternative hypothesis (Ha): Teachers' ICT literacy significantly mediates the relationship between school administrative support and teachers' ICT competence.

\section{LITERATURE REVIEW}

\section{ICT in Education in Malaysia}

According to the MOE (2016), the use of ICT is an important element in achieving the goals that have been formulated and proposed through the Malaysian Education Development Plan Report 2013-2025 (MOE, 2013). There are three main ICT policies outlined by the MOE: i) all students have skills in using ICT, ii) ICT is the main ingredient and serves as a teaching and learning tool, and iii) emphasis on the use of ICT to enhance productivity, efficiency, and effectiveness of management system.

The MOE has also implemented several strategies to enable the integration of ICT in the education field (Chan, 2002). These include:

i. Providing the latest and sufficient infrastructure that has been tested and deemed appropriate for all educational facilities,

ii. Implementing the ICT curriculum and emphasising the ICT integration in the teaching and learning process,

iii. Increasing the ICT knowledge and skills amongst students and teachers, and

iv. Increasing the ICT usage in education management.

According to Shanmugam and Balakrishnan (2018), ICT has been adapted to various fields to raise the country's name internationally. As such, new policies have been formulated and updated so that ICT is fully integrated into the national education system. In conclusion, ICT has indirectly become an important tool in the 21st century.

\section{Previous Studies}

There are a number of studies that examine the role of school administrative support in ICT integration amongst teachers. Simin and Mohammed Sani (2015) studied the role of the administrators in integrating ICT into schools. The findings showed that teachers felt motivated to use ICT in teaching and learning, but a lack of support from higher management prevented them from using it $(M=2.08, S D=$ $0.82)$. At the same time, teachers were not given the freedom to design teaching as needed $(M=2.75, S D=0.94)$. Teachers further argued that school administrators failed to provide adequate training and professional development $(M=2.86, S D=$ 0.81 ) on the use of ICT during teaching and learning for the teachers. Finally, teachers were also not given sufficient time to learn how to use ICT and adapt accordingly $(M=3.00, S D=0.76)$. Thus, researchers concluded that the implementation of ICT in the early stages must be effective so that teachers and students can utilise ICT and get the support from the school authorities. Besides, administrators are responsible for encouraging teachers to use ICT and further convince them that the use of ICT brings benefits to the teaching and learning process. Vella et al. (2017) specified that school leaders need to be critical, act as leaders, and support teachers' efforts to improve ICT integration in schools. 
A study on the technological leadership practices of ICT integration in national secondary schools in Malaysia was conducted by Abdullah et al. (2015). The findings showed that the teachers' vision and leadership were high $(M=3.64, S D=0.91)$, followed by vision and leadership $(M=3.43, S D=0.90)$, teaching and learning $(M=$ 3.38, $S D=0.90)$, professionalism and productivity $(M=3.77, S D=1.04)$, infrastructure completeness $(M=3.80, S D=0.83)$, as well as ICT support, management, and control $(M=3.82, S D=0.89)$. Researchers have concluded that school principals in Malaysia have assumed the role of technology leaders. This is in line with Salehudin (2016) who stated that school administrators are technology leaders. Researchers have therefore concluded that the role of school administrators is to act as real leaders in the development of ICT amongst the school community.

In addition, ICT literacy is strongly related to the level of ICT competence. Kim and Lee (2013) measured ICT literacy based on aspects of internet access, technology management, technology integration, technology assessment, and technology creation. On the contrary, Lau and Yuen (2014) defined ICT literacy as information literacy, computer literacy, and internet literacy, and concluded that teachers' ICT competence is important for successful implementation of ICT in schools. Meanwhile, Amua-Sekyi and Asare (2016) examined ICT literacy elements in terms of knowledge, access, and competence of lecturers at public universities in Ghana. Researchers found that respondents' ICT literacy levels were good $(3.4<M<4.5)$ in the use of ICT applications. The level of competence in using ICT was also good ( $M=$ $4.25, S D=.66)$. Researchers concluded that the survey data indicated that respondents' ICT literacy is high.

Moreover, the proficiency level of teachers using computers is still at a moderate level (Alazam, Bakar, Hamzah, \& Asmiran, 2012). According to Tasir, El Amin Abour, Abd Halim, and Harun (2012), although teachers' ICT competence was high ( $M=$ 3.95), the correlation between teacher ICT competence and teacher satisfaction ( $r=$ .496) was modest. Aslan and Zhu (2016) discovered that teachers' competence was high $(M=54.10)$ but there was no guarantee that teachers would be competent in integrating ICT into teaching $(M=52.94)$. Apart from that, Baturay et al. (2017) explained that the more frequent the day-to-day use of computers is, the higher is the teachers' computer competence while a study conducted by Aslan and Zhu (2018) found that the initial teachers' ICT competence was high $(M=3.82, S D=.74$, $p<.001$ ). However, respondents were found to be less competent in integrating ICT into teaching and learning $(M=2.85, S D=.74, p<.001)$.

Based on the various research findings of school administrative support, teacher ICT literacy, and teacher ICT competence, it can be concluded that school administrative support and teacher literacy contribute to teachers' ICT competence either directly or indirectly. Therefore, this study focuses on school administrative support, teacher ICT literacy, and teachers' ICT competence. The researchers developed and tested a model based on the variables identified through the literature review. 


\section{Related Theories}

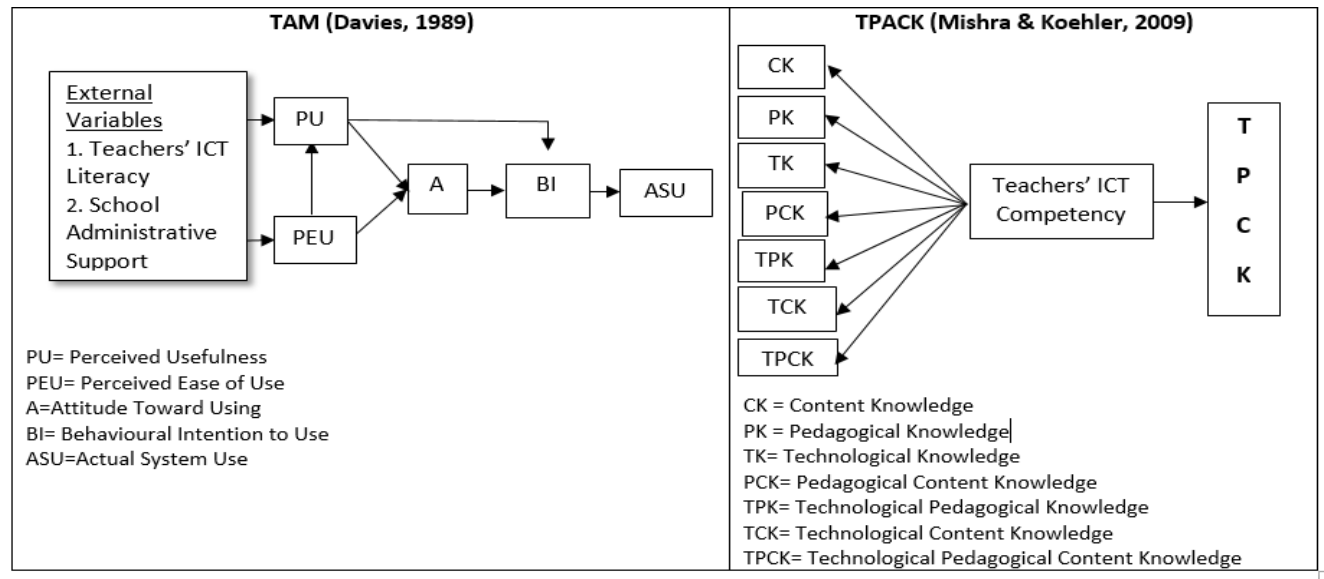

Figure 1. Technology Acceptance Model (Davies, 1989) and Technological Pedagogical and Content Knowledge Model (Mishra \& Koehler, 2009).

This study used two main theories, namely Davies' (1989) technology acceptance model (TAM) and Mishra and Koehler's (2009) technological pedagogical content knowledge (TPACK). The researchers have chosen TAM and TPACK based on the models' suitability.

Durodolu (2016) noted that the TAM is best used to study the relationship between humans and technology through perceptions of use (Perceived Usefulness) and ease of use (Perceived Ease of Use). The administrative support and ICT literacy in this study are based on the TAM.

Meanwhile, teachers' ICT competences are based on Koh et al.'s (2013) TPACK which states that TPACK is a framework that tests teachers' ICT integration of technological knowledge, pedagogical knowledge, and content knowledge. The TPACK framework is a technology integration model that focuses on effective technology integration in teaching processes involving teacher competence (Yurdakul et al., 2012).

\section{METHODOLOGY}

\section{Research Design}

This study employed a total survey design (Fowler, 2014) which requires researchers to focus on three important aspects of research, which are sampling, instrumentation, and data collection methods. Each aspect needs to be given proper attention so that the data collected are credible and valid. If there is a weakness in the implementation of any of the above aspects, the data collected may be questionable in terms of reliability and validity. Fowler (2014) recommended that it is easier for researchers to control errors if data are collected using only one method.

\section{Population and Sample}

This study was conducted in the state of Pahang. Pahang consists of 11 districts. The population of teachers teaching in the National Schools (SK), National-Type Schools (Chinese) (SJKC), National-Type Schools (Tamil) (SJKT), and Government-Funded Religious Schools (SABK) totalled 14648 people across Pahang (Educational Planning 
and Research Division [EPRD], MOE, 2018). In this study, only the National Schools (SK) were involved. Teachers who teach at SJKC, SJKT, and SABK are excluded from this study.

In this study, Hair, Anderson, Tatham, and Black (2010) proposed 240 respondents (48 item X 5) for the pilot study and actual study. The researchers used 668 respondents in the pilot study because the researchers had access to the list of population of primary school teachers in Pahang as provided by the EPRD, MOE (2018). Similarly, 685 teachers were selected randomly for the actual study. The stratified cluster sampling method was utilised by the researchers to randomly select the pilot study sample and the actual study sample. A total of 1353 respondents were primary school teachers from selected schools in Pahang. School administrators including principals, senior administration assistant teachers, senior student affairs teachers, senior extracurricular teachers, and school supervisors were excluded from this study. Both the pilot and actual data were collected from January 2019 to March 2019.

\section{Instrumentation}

The instrument of this study consists of four sections. Part I collects information on the demographic background of respondents. Part II measures the school administrative support, Part III measures teacher ICT literacy, and Part IV measures teachers' ICT competence. All of the items in Part II, Part III, and Part IV are adapted from instruments that have been used in the previous studies. Please refer to Table 1.

Table 1: Number of Items Based on the Parts of Instrument

\begin{tabular}{lcc}
\hline Variable & Instrument (Source) & Number of Item \\
\hline School Administrative Support & Simin and Mohammed Sani (2015) & 5 \\
Teachers' ICT Literacy & Lau and Yuen (2014) & 17 \\
Teacher's ICT Competence & Koh et al. (2012) & 29 \\
\hline Total Item & & 51 \\
\hline
\end{tabular}

Table 1 shows the original sources of instruments used in this study, which are school leadership (Simin \& Mohammed Sani, 2015), teachers' ICT literacy (Lau \& Yuen, 2014), and teachers' ICT competence (Koh et al., 2012).

Researchers used the back translation method (Brislin, 1970) to translate all items written in English into Malay. The items were translated and verified by two content and language experts and one language expert. All items were measured using a five-point Likert scale ranging from $1=$ Strongly Disagree (SD), $2=$ Disagree (D), $3=$ Undecided (U), 4 = Agree (A), and 5 = Strongly Agree (SA).

\section{Pilot Study}

A pilot study was conducted to determine the reliability and validity of the instrument. The researchers employed the stratified cluster sampling to select a sample for the pilot study. A total of 668 questionnaires were distributed in the Kuantan district involving a total of three urban schools and six rural schools. After 
the data screening process, only 523 sets of questionnaires were analysed for pilot study. The researchers have excluded nine cases of outliers based on the Mahalanobis distance (MD) (Byrne, 2001). A total of 514 teachers were used as respondents for the pilot study. The researchers applied a two-step process as recommended by Byrne (2001) and Pedhazur (1997). The first step involves establishing the validity of the full measurement model, whereas the second step involves fitting of the full structural model. The Cronbach's alpha values for the instrument are displayed in Table 2.

Table 2: Reliability of Instruments

\begin{tabular}{lcc}
\hline Variable & Number of Item & $\boldsymbol{r}_{\boldsymbol{\alpha}}$ (Cronbach's alpha) \\
\hline School Administrative Support & 3 & $.515^{*}$ \\
Teachers' ICT Literacy & 16 & .756 \\
Teacher's ICT Competence & 29 & .939 \\
\hline Overall & 48 & .954
\end{tabular}

* considered 'acceptable' (Taber, 2017)

Table 2 shows the number of items in each construct after the data were screened. The researchers excluded two items and one item from school administrative support and teachers' ICT literacy respectively. These items were excluded because the items had a 8 weight lower than .40 (Chin, 1998). Cronbach's alpha value for all items was .954. According to Taber (2017), Cronbach's alpha values between .45-.98 are considered 'acceptable' and values between $.45-.96$ are considered 'sufficient'.

The validity of the study instrument was determined using confirmatory factor analysis (CFA). Data were taken from the pilot study $(n=514)$ to determine the model fit. Bryne (2010) used the following index fit value as criteria to achieve a good fit: $C M I N / d f \leq 5.00, G F I \geq .90$ (absolute fit), $C F I \geq .90$ (increment fit), and RMSEA $\leq .05$ (or $\leq .08$, absolute fit). As such, the full measurement model exhibited a good fit with chi-square value $=212.406 ; d f=58 ; p<.001 ; \mathrm{CMIN} / d f=3.662 ; \mathrm{GFI}=.938 ; \mathrm{CFI}$ $=.941 ;$ and $\mathrm{RMSEA}=.072$.

\section{Data Collection}

The researchers used the self-administered questionnaire (SAQ) method (Lavrakas, 2008) to collect data for the pilot study and the actual study. The researchers personally distributed the questionnaire to the respondents and the respondents answered the questionnaire either individually or in groups without any intervention from the researchers. The data were screened for outliers which were excluded from further analyses.

\section{Data Analysis}

The researchers utilised the Statistical Package for the Social Science (SPSS) version 23 and AMOS version 23 to validate the full measurement model and model fitting. Hypotheses related to the role of mediator in the model was tested at $p<.05$. From an analytical standpoint, the structural equation modelling (SEM) describes causal relationships (Byrne, 2001; Hoyle, 1995; Kaplan, 2011; Kline, 2011; Schumacker \& 
Lomax, 2004) among school administrative support, teachers' ICT literacy, and teachers' ICT competence in the mediation model.

\section{RESULTS AND DISCUSSION}

\section{Respondents' Demographics}

Table 3: Respondents' Demographic Profile of Actual Study

\begin{tabular}{lcccc}
\hline Demographics & $\begin{array}{c}\text { Teachers' ICT } \\
\text { Literacy Mean (SD) }\end{array}$ & $\begin{array}{c}\text { Teachers' ICT } \\
\text { Competence Mean (SD) }\end{array}$ & $\mathbf{n}$ & $\%$ \\
\hline Gender & $62.77(9.04)$ & $106.33(14.08)$ & 135 & 25.5 \\
Male & $62.60(7.34)$ & $104.01(12.59)$ & 395 & 74.5 \\
Female & & & & \\
Teaching Experience & $64.96(6.90)$ & $107.13(12.40)$ & 121 & 22.8 \\
Less than 10 years & $62.77(7.87)$ & $104.61(12.73)$ & 262 & 49.4 \\
$11-20$ years & $61.13(8.01)$ & $103.17(14.02)$ & 119 & 22.5 \\
$21-30$ years & $57.79(7.80)$ & $99.68(12.16)$ & 28 & 5.3 \\
Over 30 years & & & & \\
School Location & $62.05(8.39)$ & $104.28(13.60)$ & 129 & 25.3 \\
$\quad$ Urban & $62.83(7.61)$ & $104.70(13.02)$ & 401 & 75.7 \\
$\quad$ Rural & &
\end{tabular}

Table 3 shows the demographic profile of the respondents for the actual study according to the mean $(M)$ and standard deviation $(S D)$ in the urban and rural areas. The researchers distributed 685 questionnaires to three districts in Pahang involving 7 schools in Raub district, 22 schools in Lipis district, and 5 schools in Bentong district. After the data filtering process, only 540 sets of questionnaires were analysed. The researchers excluded 10 outliers and the total number of respondents for the actual study was 530. The findings showed that the majority of the respondents in this study were female teachers $(n=395)$. Almost half of teachers had 11 to 20 years $(n=262)$ of experience in education. More data were collected from teachers in rural schools $(n=401)$ compared to urban schools $(n=129)$.

Table 3 also shows the mean and standard deviation of ICT literacy as well as teachers' ICT competence. Scoring of the Likert scale, as a summated rating scale the sub-scores and total scores is a sum or average of the respondents' response to the multiple items on the instrument (Kerlinger, 2000). Cut off total scores for ICT literacy and ICT competence were determined using z-score. A standardized z-score of .7 is used as a cut off score for ICT literacy and ICT competence. Z-score of .7 corresponds to the 76th percentile. Ankur Barua et al. (2014) suggested that 'Most of the common parameters in statistical methods are considered to be stronger if they are more than 75th percentile or 75\% in ideal situations" (p.55). Therefore the cut off total score for ICT literacy and ICT competence is 68 and 113 respectively. In 
this study, a raw total score higher than 68 for ICT literacy it is considered as 'high'. As for ICT competence, a raw total score higher than 113 it is categorized as 'high'. The findings showed that ICT literacy among male teachers $(M=62.77, S D=9.04)$ and female teachers $(M=62.60, S D=7.34$ ) was quite similar, whereas the mean and standard deviation of teachers' ICT literacy for teacher experience showed little difference. The mean score for teaching experience of less than 10 years was higher than the 11-20 years category, whereas the teaching experience of the 11 to 20 years category was much higher than 21-30 years and over 30 years of teaching experience. The findings indicated that ICT literacy amongst teachers with less than 10 years of experience was the highest with mean values of 64.96 and $S D$ of 6.90. On the contrary, teachers who served over 30 years had the lowest ICT literacy. The mean values of ICT literacy among urban teachers $(M=62.05 ; S D=8.39)$ and rural $(M=62.83 ; S D=7.61)$ were almost similar. This indicates that the mean value of rural primary school teachers is slightly higher than the mean of primary urban school teachers.

ICT competence of male teachers was higher $(M=106.33, S D=14.08)$ than that of female teachers $(M=104.01, S D=12.59)$. The findings showed that teachers with less than 10 years of teaching experience had higher ICT competence $(M=107.13, S D$ $=12.40$ ) compared to the other three groups. On the other hand, ICT competences of urban $(M=104.28, S D=13.60)$ and rural schools $(M=104.70, S D=13.02)$ are comparable. The mean for rural schools is higher than the urban schools.

\section{Research Findings}

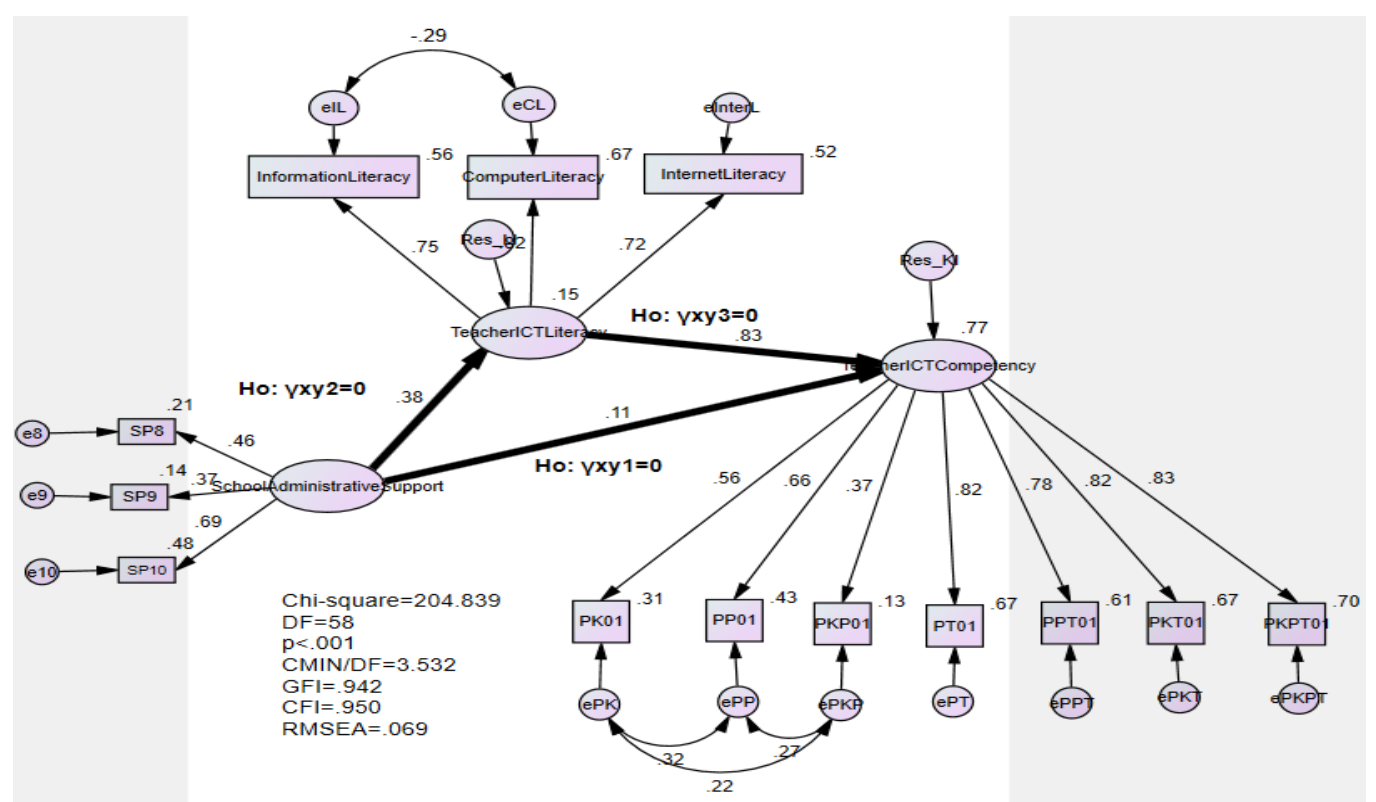

Figure 2. Direct and Indirect Effects of School Administrative Support on Teachers' ICT Competence and Teachers' ICT Literacy as a Mediator.

According to Figure 2, there are three variables which are school administrative support, teachers' ICT competence, and teachers' ICT literacy. Figure 2 indicates the fitted structural model with chi-square $=204.839, d f=58, p<.001, \mathrm{CMIN} / d f=3.532$, $\mathrm{GFI}=.942, \mathrm{CFI}=.950$, and RMSEA $=.069$. The researchers used bootstrapping to 
allow analysis for a non-normal multivariate distribution in the actual data (kurtosis $=66.945, \mathrm{c} . r=39.020)$. The findings showed a direct effect of school administrative support $\rightarrow$ teachers' ICT competence $(\beta=.109, p<.05, \mathrm{Cl} 95 \%=.011, .224)$, effect of school administrative support $\rightarrow$ teachers' ICT literacy $(\beta=.381, p<.05, \mathrm{Cl} 95 \%=$ $.257, .510)$, and teachers' ICT literacy $\rightarrow$ teacher's ICT competence $(\beta=.827, p<.05$, $\mathrm{Cl} 95 \%=.741, .892)$. The indirect effect was .381*.827 $=.315, p<.05$. Hence, the total effect was $.315+.109=.424$.

The researchers concluded that there is a statistically significant direct effect ( $p<$ .05) of school administrative support on teachers' ICT competence and a statistically significant indirect effect $(p<.05)$ of school administrative support on teachers' ICT competence with teachers' ICT literacy as a mediator.

The $R^{2}$ value for teachers' ICT competence is .77. This indicates that $77 \%$ of the variance in teachers' ICT competence are accounted by the school administrative support and teachers' ICT literacy. The researchers concluded that the overall variance in school administrative support and teachers' ICT literacy can explain most of the variance in teachers' ICT competence.

Statistical hypothesis testing on mediators in the study: school administrative support $\rightarrow$ teachers' ICT competence through teacher ICT literacy as a mediator.

$$
\begin{aligned}
& H o: \gamma x y 1=\gamma x y 2=\gamma x y 3=0 \\
& H a: \gamma x y 1=\gamma x y 2=\gamma x y 3 \neq 0
\end{aligned}
$$

The researchers reject Ho: $\gamma x y 1=\gamma x y 2=\gamma x y 3=0$ and accept Ha: $\gamma x y 1=\gamma x y 2=\gamma x y 3 \neq$ 0 . The researchers concluded that there is a statistically significant relationship between school administrative support $\rightarrow$ teachers' ICT literacy $(p<.05)$, teachers' ICT literacy $\rightarrow$ teachers' ICT competence $(p<.05)$ and school administrative support $\rightarrow$ teachers' ICT competence $(p<.05)$. Therefore, teachers' ICT literacy plays the role of partial mediator.

Table 4: Mediator Summary: Teachers' ICT literacy

School Administrative Support - Teachers' ICT Literacy - Teachers' ICT Competence

\begin{tabular}{lcccc}
\hline & B & S.E. & C.R & p \\
\hline Teachers' ICT Literacy <--- School Administrative Support & .381 & .315 & 4.809 & $* * *$ \\
Teachers' ICT Competence <--- Teacher ICT Literacy & .827 & .049 & 13.457 & $* * *$ \\
Teachers' ICT Competence <--- Teacher ICT Literacy & .109 & .154 & 2.264 & $.024 *$
\end{tabular}

* significant at $p<.05$

Based on Table 4, the researchers concluded that teachers' ICT literacy serves as a partial mediator in this study. The direct effect of Teachers' ICT Competence <--School Administrative Support is $\beta=.109$. The indirect effect of Teachers' ICT Literacy <--- School Administrative Support is $\beta=.381$ and Teachers' ICT Competence $<---$ Teachers' ICT Literacy is $\beta=.827$. Table 4 also indicates that there are statistically significant relationships $(p<.05)$ between the direct effect of school 
administrative support and teachers' ICT competence, and school administrative support and teachers' ICT competence with teachers' ICT literacy as a mediator.

\section{CONCLUSION}

The school administrative support for ICT-related issues also plays an important role in integrating ICT into teaching and learning. Teachers stated that they were given the freedom to design teaching and learning activities with the help of technology. As school administrators, school principals should give teachers more time to improve their ICT skills so that teachers feel comfortable using ICT in the classroom. Previous studies conducted by Abdullah et al. (2015), Blau and Shamir-Inbal (2016), Salehudin (2016), Simin and Mohammad Sani (2015), Thannimalai and Raman (2018), and Vella et al. (2017) further support the importance of administrative support for ICT integration in schools.

Teachers' ICT literacy mediates school administrative support and teachers' ICT competence. This indicates that school administrative support plays an important role in the formation of ICT literacy and thus teacher's competence in integrating ICT into the classroom. According to Davies (1989), the school administrative support and ICT literacy as external factors are complementary as these two factors play an important role in realising the MOE's desire to integrate ICT into education.

School administrators, particularly the school principals, should encourage the use of ICT in teaching and learning by giving teachers the freedom to design teaching and learning activities with the help of technology. Teachers should also be given more time to learn ICT skills so that they can feel comfortable during teaching and learning. One of the ways for teachers to improve ICT skills is through provision of adequate ICT training. Formally, head teachers can encourage their teachers to take ICT-related courses through in-service teacher training. School administrative support not only influences how the existing ICT facilities are being optimised by the school, but the head teachers can also influence teachers' ICT literacy on the ICT integration in teaching and learning. The importance of school administrative support, especially the role of principals in the development of information literacy, internet literacy, and computer literacy amongst teachers, cannot be overstated as these factors directly and indirectly influence the formation of ICT competences amongst teachers.

The school administrative support directly affects the development of ICT literacy amongst teachers, namely mastery of information literacy, internet literacy, and computer literacy. This clearly shows that administrative support has emerged as one of the key factors in the process of implementing ICT in schools. Support and encouragement should be provided by school administrators to the teachers by providing opportunities to enhance teacher professionalism. Furthermore, teachers' motivation for improving the quality of ICT usage in the classroom can be achieved. School administrators are encouraged to play a more proactive role in enhancing ICT competences among teachers besides acting as a role model for their teachers in integrating ICT into the classroom.

The support of school administrators plays a critical role in determining the success or failure of an effort to integrate ICT into schools (Thannimalai \& Raman, 2018). Thannimalai and Raman (2018) found that the level of principals' technology leadership included visionary leadership, digital learning culture, excellence in 
professional practice, system improvement, and digital citizenship among Malaysian secondary schools in Kedah. In addition, the technology leadership level of principals is found to be a good predictor of technology integration amongst teachers. Researchers further suggested that more effective technology leadership should be further developed for school administrators. This study also concludes that administrative support for teachers' professional development in schools indirectly promotes technology integration in the classroom.

Head teachers who practise technological leadership can create a more conducive environment so that the success in integrating ICT into education can be guaranteed. Technology can be integrated and implemented effectively in schools if the school administration itself supports the usage, learning of technology, and use of technology in their daily tasks; provides support for teachers; supports teachers to make changes; and provides training opportunities for themselves and other teachers. Researchers argued that administrative support through technological leadership is more needed in the use of ICT in schools. It can be concluded that the support of the school administration, especially the head teacher, plays an important role in the formation of teachers' ICT literacy and teachers' competence in implementing ICT in the classroom.

Teachers who have the support of the administrators have a positive attitude and a high degree of readiness to master the information skills, the internet literacy, and the computer literacy with the provision of complete infrastructure. The influence of teachers' ICT literacy on ICT integration has been studied by several researchers (Amua-Sekyi \& Asare, 2016; Kim \& Lee, 2013; Lau \& Yuen, 2014; Mahmud \& Ismail, 2010; Salehudin, 2016) who pointed out that teachers' ICT literacy plays an important role in shaping teachers' ICT competence in the classroom.

Teachers' ICT literacy influences the development of ICT competence amongst teachers. All three components of ICT literacy play a critical role in developing teachers' ICT competences. However, Mahmud and Ismail (2010) found that teacher literacy such as teachers' ICT literacy and teachers' ICT competence are still at a moderate level. Teachers' ICT literacy acts as a partial mediator through administrative support to teachers' ICT literacy, teachers' ICT literacy to teachers' ICT competence, and through administrative support to teachers' ICT competence. The researchers concluded that teachers' ICT literacy plays a role as a mediator and plays an important role in this research model.

It is undeniable that school administrative support and teachers' ICT literacy (Davies, 1989), as well as teachers' ICT competence (Mishra \& Koehler, 2009) play an important role in adapting ICT in the classroom. However, upon closer scrutiny it can be identified that administrative support will further influence the formation of teachers' ICT literacy. For future studies, the school administrators should ensure that the ICT facilities at the school are usable and technical assistance is provided by the school if teachers have problems with access to computer labs or using ICT equipment. School administrators also need to ensure that teachers are given more time and opportunities to learn ICT skills so that they can feel comfortable during teaching and learning in the classroom. This can be done by encouraging teachers to enhance their ICT knowledge and skills through ICT-related courses that are offered through in-service training. 
Training on the use of ICT in teaching and learning not only enhances teacher professionalism but also makes teachers more willing to integrate ICT into the classroom. Teachers should therefore ensure that ICT literacy and ICT competence are always given due attention and nurtured to suit the current needs of ICT. Further support from the school administration needs to be enhanced so that teachers are always positive about ICT and are ready to implement ICT in the classroom.

The researchers recommend that the study be extended to more advanced states such as Selangor and the Federal Territory of Kuala Lumpur so that comparisons can be made with regard to the impact of the digital divide. In addition, technological leadership within the school administration is recommended to be studied in depth so that related elements such as school administrative support, teacher ICT literacy, and teacher professionalism can be identified for technological leadership training purposes.

\section{REFERENCES}

Abdullah, N., Khalid, H., \& Mohd Hamzah, M. I. (2015, March 9-10). Amalan kepimpinan teknologi pengetua dalam pengintegrasian ICT di sekolah menengah kebangsaan di Malaysia: Proceedings of the 3rd Global Summit on Education (GSE 2015) (pp. 684-694). Kuala Lumpur: WorldConferences.net.

Adams, D., A. Samat, S. N., \& Abu Samah, H. (2018). Teacher leadership: Going beyond classroom. International Online of Educational Leadership, 2(1), pp. $1-3$.

Alazam, A.-O., Bakar, A. R., Hamzah, R., \& Asmiran, S. (2012). Teachers' ICT skills and ICT integration in the classroom: The case of vocational and technical teachers in Malaysia. Creative Education, 3(8), 70-76. https://doi.org/10.4236/ce.2012.38B016

Ammah, E. S. (2017). Pengembangan ICT sebagai solusi inovatif pembelajaran Bahasa Indonesia di era tsunami digital. Tarbiyatuna, 1(1), 48-57.

Amua-Sekyi, E. T., \& Asare, P. Y. (2016). A survey of information communication technology literacy among lecturers. Information and Knowledge Management, 6(8), 1-7. Retrieved from www.iiste.org/Journals/index.php/IKM/article/view/32369

Aslan, A., \& Zhu, C. (2016). Investigating variables predicting Turkish pre-service teachers' integration of ICT into teaching practices. British Journal of Educational Technology, 48(2), 552-570. https://doi.org/10.1111/bjet.12437

Aslan, A., \& Zhu, C. (2018). Starting teachers ' integration of ICT into their teaching practices in the lower secondary schools in Turkey. Educational Sciences: Theory \& Practice, 18(1), 23-45. https://doi.org/10.12738/estp.2018.1.0431

Barua, A., Kademane, K., Das, B., Gubbiyappa, K. S., Verma, R. K., \& Al-Dubai, S. A. R. (2014). A tool for decision-making in norm-referenced survey questionnaires with items of ordinal variables. International Journal of Collaborative Research on Internal Medicine \& Public Health, 6, 52-63

Baturay, M. H., Gokcearslan, Ş., \& Ke, F. (2017). The relationship among pre-service teachers' computer competence, attitude towards computer-assisted education, and intention of technology acceptance. International Journal of Technology Enhanced Learning, 9(1), 1-13. https://doi.org/10.1504/IJTEL.2017.10003119 
Blau, I., \& Shamir-Inbal, T. (2016). Digital competences and long-term ICT integration in school culture: The perspective of elementary school leaders. Education and Information Technologies, 22(3), 769-787. https://doi.org/10.1007/s10639-015-9456-7

Brislin, R. W. (1970). The wording and translation of research instruments. In W. J. Lonner \& J. W. Berry (Eds.), Cross-cultural research and methodology series (Vol. 8): Field methods in cross-cultural research (pp. 137-164). Newbury Park, CA: SAGE Publications, Inc.

Byrne, B. M. (2001). Structural equation modeling with AMOS: Basic concepts, applications, and programming. New York: Psychology Press. https://doi.org/10.4324/9781410600219

Chan, F.-M. (2002, October 15-22). ICT in Malaysian schools: Policy and strategies. Paper presented at a Workshop on the Promotion of ICT in Education to Narrow the Digital Divide, Tokyo, Japan.

Chin, W. W. (1998). Commentary: Issues and opinion on structural equation modeling. Management Information Systems Quarterly, 22(1), vii-xvi.

Davis, F. D. (1989). Perceived usefulness, perceived ease of use, and user acceptance of information technology. Management Information Systems Quarterly, 13(3), 319-340.

Durodolu, O. O. (2016). Technology Acceptance Model as a predictor of using information system to acquire information literacy skills. Library Philosophy and Practice, 1450 (e-journal), 3-28. Retrieved from http://digitalcommons.unl.edu/libphilprac\%0Ahttp://digitalcommons.unl.ed u/libphilprac/1450

Education Planning and Research Development (EPRD, MOE). (2018). Data bilangan guru sekolah rendah negeri Pahang. Kementerian Pendidikan Malaysia, 136(1), 23-42.

Fong, S. F., Ch'ng, P. E., \& Por, F. P. (2013). Development of ICT competency standard using the Delphi technique. Procedia - Social and Behavioral Sciences, 103, 299-314. https://doi.org/10.1016/j.sbspro.2013.10.338

Fowler, F. J. (2014). Applied social research methods: Survey research methods (4th ed.). Thousand Oaks, CA: SAGE Publications, Inc. doi: $10.4135 / 9781452230184$

Hoyle, R. H. (Ed.). (1995). Structural equation modeling: Concepts, issues and applications. Thousand Oaks, CA: SAGE Publications.

Kaplan, D. (2011). Structural equation modeling. Thousand Oaks, CA: SAGE Publications.

Kerlinger, F. (2000). Foundations of behavioral research. Harcourt College Publishers.

Kim, J., \& Lee, W. (2013). Meanings of criteria and norms: Analyses and comparisons of ICT literacy competencies of middle school students. Computers and Education, 64, 81-94. https://doi.org/10.1016/j.compedu.2012.12.018

Kline, R. B. (2011). Principles and practice of structural equation modeling (3rd ed.). New York: The Guildford Press.

Koh, J. H. L., Chai, C. S., \& Tsai, C.-C. (2012). Examining practicing teachers' perceptions of technological pedagogical content knowledge (TPACK) pathways: A structural equation modeling approach. Instructional Science, 41(4), 793-809. https://doi.org/10.1007/s11251-012-9249-y

Lau, W. W. F., \& Yuen, A. H. K. (2014). Developing and validating of a perceived ICT literacy scale for junior secondary school students: Pedagogical and 
educational contributions. Computers and Education, 78, 1-9. https://doi.org/10.1016/j.compedu.2014.04.016

Lavrakas, P. J. (2008). Self-administered questionnaire. In Encyclopedia of survey research methods (Vols. 1-10) (p. 4135). Thousand Oaks, CA: SAGE Publications, Inc. doi: 10.4135/9781412963947

Koehler, M. J., \& Mishra, P. (2009). What is technological pedagogical content knowledge? Contemporary Issues in Technology and Teacher Education, 9(1), 60-70.

Leong, M. W., Chua, Y. P., Kannan, S., \& A. Moulod, S. (2016). Relationship between teacher ICT competency and teacher acceptance and use of School Management System (SMS). Malaysian Online Journal of Educational Technology, 4(4), 36-52.

Mahmud, R., \& Ismail, M. A. (2010). Impact of training and experience in using ICT on in-service teachers' basic ICT literacy. Malaysian Journal of Educational Technology, 10(2), 5-10.

Ministry of Education Malaysia (MOE). (2012). Dasar Pendidikan Kebangsaan. Putrajaya: Bahagian Perancangan dan Penyelidikan Dasar Pendidikan, Kementerian Pelajaran Malaysia.

Ministry of Education Malaysia (MOE). (2013). Pelan Pembangunan Pendidikan Malaysia 2013-2025. Putrajaya: Kementerian Pendidikan Malaysia.

Ministry of Education Malaysia (MOE). (2016). Dokumentasi kajian \& laporan pemantauan 2013-2015. Putrajaya: Kementerian Pendidikan Malaysia.

Mohamed, A., Abdul Razak, A. Z., \& Abdullah, Z. (2018). Teacher leadership and teacher professional learning in schools of Maldives. International Online Journal of Educational Leadership, 2(2), 36-50.

Mohd Sani, R. (2016, October 25-27). Pembinaan kerangka standard kompetensi literasi ICT kebangsaan: Kajian Delphi: Proceedings of the International Seminar on Generating Knowledge Through Research (ICECRS) (Vol. 1[1], pp. 113-122). Sintok: Universiti Utara Malaysia. doi: https://doi.org/10.21070/picecrs.v1i1.585

Pedhazur, E. J. (1997). Multiple regression in behavioral research: Explanation and prediction (3rd ed.). New York: Christopher P. Klein/Wadsworth-Thomson Learning, Inc.

Rajalahti, T., \& Kvalheim, O. M. (2011). Multivariate data analysis in pharmaceutics: A tutorial review. International Journal of Pharmaceutics, 417(1-2), 280290. https://doi.org/10.1016/j.ijpharm.2011.02.019

Salehudin, M. H. F. (2016). Pengaruh kepimpinan teknologi dan penggunaan teknologi maklumat dan komunikasi di sekolah: Satu analisis. International Journal of Education, Psychology and Counseling, 1(2), 17-23.

Schumacker, R. E., \& Lomax, R. G. (2004). A beginner's guide to structural equation modeling (2nd ed.). Hillsdale, NJ: Erlbaum.

Shanmugam, K., \& Balakrishnan, B. (2018). Kerangka panduan efektif pengajaran dan pemudahcaraan $(\mathrm{PdPC})$ sains menggunakan information communication technology (ICT) di Sekolah Jenis Kebangsaan Tamil (SJK) (TAMIL). Sains Humanika, 10(1), 25-35. Retrieved from https://sainshumanika.utm.my/index.php/sainshumanika/article/view/1322 $/ 758$

Simin, G., \& Mohammed Sani, I. (2015). Effectiveness of ICT integration in Malaysian schools: A quantitative analysis. International Research Journal for Quality in Education, 2(8), 1-12. 
Taber, K. S. (2018). The use of Cronbach's alpha when developing and reporting research instruments in science education. Research in Science Education, 48(6), 1273-1296. https://doi.org/10.1007/s11165-016-9602-2

Tasir, Z., El Amin Abour, M. K., Abd Halim, N. D., \& Harun, J. (2012). Relationship between teachers' ICT competency, confidence level, and satisfaction toward ICT training programmes: A case study among postgraduate students. The Turkish Online Journal of Educational Technology, 11(1), 138144.

Thannimalai, R., \& Raman, A. (2018). The influence of principals' technology leadership and professional development on teachers' technology integration in secondary schools. Malaysian Journal of Learning and Instruction, 15(1), 203-228.

Vanderlinde, R., Aesaert, K., \& Van Braak, J. (2014). Institutionalised ICT use in primary education: A multilevel analysis. Computers and Education, 72, 110. https://doi.org/10.1016/j.compedu.2013.10.007

Veeriah, P., Chua, Y. P., \& Siaw, Y. L. (2017). Principal's transformational leadership and teachers' affective commitment in primary cluster schools in Selangor. International Online Journal of Educational Leadership, 1(1), 60-89.

Vella, S. F., Burmeister, O. K., Ceric, A., \& Barnden, A. (2017). A systematic narrative review of literature on Catholic schools in Australia to better understand the role of School Leadership deploying and integrating Information and Communication Technology (ICT) in this environment. eJournal of Catholic Education in Australasia, 3(1), 1-16.

Vitanova, V., Atanasova-Pachemska, T., Iliev, D., \& Pachemska, S. (2015). Factors affecting the development of ICT competencies of teachers in primary schools. Procedia - Social and Behavioral Sciences, 191, 1087-1094. https://doi.org/10.1016/j.sbspro.2015.04.344

Yurdakul, I. K., Odabasi, H. F., Kilicer, K., Coklar, A. N., Birinci, G., \& Kurt, A. A. (2012). The development, validity and reliability of TPACK-deep: A technological pedagogical content knowledge scale. Computers and Education, 58(3), 964977. https://doi.org/10.1016/j.compedu.2011.10.012 